\title{
MID-HOLOCENE SEA LEVEL CHANGES IN SRI LANKA
}

\author{
U. WEERAKKODY \\ Department of Geograpby, University of Rubuna, Matara, Sri Lanka.
}

(Date of receipt : 03 March 1987)

(Date of acceptance : 22 September 1987)

\begin{abstract}
Sea level changes due to various factors cause shifts in the coastline of Sri Lanka, as in other regions of the World. They are valuable in understanding the long-term, factors that cause coastal erosion. The Mid-Holocene sea level changes were studied using geomorphological maps aided by field work and a laboratory analysis of materials. The bay beaches, mid-bay bars, barriers, spits, shell beds, wave-cut terraces, etc., which originated from an early marine transgression were observed along the inland areas of the Kalametiya, Lunama and Koholankala lagoons and the Minihagalkanda beds of the Southeast coast. They submerged the land to form deep embayments and barrier chains. Information obtained through radiocarbon: dating and previous studies prove that these sea levels prevailed during $4040 \pm 70 \mathrm{BP}$ to $3620 \pm 70 \mathrm{BP}$.
\end{abstract}

\section{Introduction}

Ever since the beginning of the Holocene period, fluctuations in sea levels have changed the positions of many coasts of the world. Rising sea levels and falling sea levels are normally referred to as marine transgressions and regressions respectively, and these events cause degradation and progradation of a coast, by submergence and emergence.

The principal factors causing sea level changes on a global scale can be summarized as follows;

a) Long-term tectonic changes causing the relative sea level to rise or fall. This is known as tectono-eustacy.

b) Alternating glaciation and deglaciation affecting changes of ocean water. During glaciation, there is an increased concentration of water on land resulting in a proportional drop in sea level. This is called glacio-eustacy.

c) Unloading and loading of ice from or on the Earth's crust leads to gravitational disequilibrium between different rock strata. This is known as glacio-isostasy. Glacio-isostásy may cause a coast to emerge or submerge. Similarly, hydro-isostasy refers to unloading and loading of water from or on ocean floors, leading to gravitational disequilibrium. This long-term process can also lead to emergence or submergence of coasts.

Seasonal changes in the mean sea level of the ocean are caused by the combined effect of factors such as tidal changes, changes in local atmospheric pressures, changes in wind velocity and direction, melting of ice or 
freezing of water anywhere, etc, and the result is the seasonal emergence and submergence of a strip of beach.

During the last five millenia, the coastal zone of Sri Lanka has been subjected to various geomorphological changes governed by sea level changes resulting submergence and emergence of land strips. Early bays in MidHolocene have been cut off by barrier chains and they formed into lagoons, while the barriers are being crowned by elongated continuous ridges of dunes. Changes of river outfalls and obstruction of estuaries can be observed along the Southwest, Southeast and Northeast coast of Sri Lanka. In addition, the Southwest coast is endangered by coastal erosion, losing extensive land portions, 11 and during the last two centuries, for example, some headlands, points, extensive sandy beaches, etc, have been completely washed away. ${ }^{17}$ Several causes have contributed to this such as geological, geomorphological, anthropogenic, etc. ${ }^{13}$ The sea level changes since the MidHolocene are one of the most effective factors of these changes in Sri Lanka. Therefore, a study of sea level changes of the Island since the Mid-Holocene will contribute towards understanding the causal factors on a long-term basis.

The position of the coastline of Sri Lanka fluctuated substantially during the Quaternary Era and studies have been conducted or mentioned by Wayland, ${ }^{16}$ Coates, ${ }^{2}$ Deraniyagala, ${ }^{5}$ Swan, ${ }^{11,12}$ and Cooray. ${ }^{3}$ However, no attention has been paid to the position of the Mid-Holocene (since 5000 BP) with the aid of geomorphological evidence and radiocarbon dating of samples.

\section{Area}

The coastal zone stretching from Kalametiya to Minihagalkanda covers long and diversified tracts of coastal environments. The present study concentrates upon three selected coastal tracts, namely, the Kalametiya-Lunama lagoons, the Koholankala lagoon and the Minihagalkanda beds.

Lying in the southeastern extremity of Sri Lanka, the study area is dominated by marine influences operating on deeply weathered, metamorphic rocks that have been levelled to a slightly to moderately dissected planation surface that have been called 'the coastal peneplain' by Adams ${ }^{1}$ and Wadia. ${ }^{15}$

The geomorphology of the area is characterized by a series of depositional coastal features in the littoral zone and the adjacent hinterland and by fluvial deposits and two recognizable planation surfaces in the hinterland. The planation surfaces formed in Precambrian and Palaeozoic metamorphic 
rocks can be observed to form headianus at several places in the littoral zone.

The coastal area is covered by predominantly Quaternary deposits that can be found along beaches, lagoons, estuaries, lakes and in river flood plains as well as the slopes of planation surfaces. A large part of the study area is covered by beaches and dune sands forming a belt of unconsolidated materials parallel to the coast. The beach sands are not restricted to the littoral zone, but can also be found in the fossilized beaches at some places in the immediate hinterland. In subrecent times, chains of barriers have formed closing the lagoons. ${ }^{19}$ In later periods, most of these barriers were reworked by wind action. At many places, therefore, the dunes are situated on barriers.

\section{Materials and Methods}

Evidences derived from genetic geomorphological surveys compiled into a map of an area reveals former land forms which originated from marine and other processes. Therefore, such a survey would recognize former coastlines resulting from higher sea levels. The former coastlines associated with beaches, barriers, spits, etc, denote the sea level raised by early marine transgressions. Thus geomorphological maps consisting of former landforms and coastal evolutionary stages were studied so as to demarcate the position of the former coastline.

The method of mapping landforms of an area by the ITC*system of geomorphological survey, uses aerial photographs and other remote sensing techniques. ${ }^{14,18}$ This system is an applied geomorphological discipline which provides a concise and systematic picture of landforms and related phenomena of an area. According to this method, aerial photographs i.e. B \& W Panchromatic infrared, False colour and satellite imagery i.e. Landsat 3, SPOT or radar imagery as required, are interpreted using a mirror stereoscope and other instruments, taking into consideration the tone, mottling pattern, contrast, texture, etc, of the photographs or imagery. The interpreted features are normally elaborated by field work and/or laboratory analysis of materials. A geomorphological map so compiled shows types of landforms, morphometric, morphogenetic and morphochronological properties of landforms as well as a classification of landforms by origin into structural, denudational, marine, fluvial, aeolian, etc, under a well arranged key. Therefore, the ITC system serves to understand morphology, morphometry, genesis, as well as the chronology of the landforms of an area using geomorphological maps.

The geomorphological maps studied according to the ITC system were from Kalametiya-Lunama lagoons, ${ }^{21}$ the Koholankala lagoon, ${ }^{20}$ and the

\footnotetext{
- International Institute for Aerospace Survey and Earth Sciences (ITC)
} 
Minihagalkanda beds. ${ }^{19}$ The landforms of the maps have been classified according to the ITC systems and field work has been carried out so as to check the landforms included on maps, especially those that originated from marine action, and also to collect representative samples. The clarification of the landforms included on maps and the correct identification of landforms were also made possible through field work.

The representative samples were studied at the sedimentological laboratory at the Department of Geography, University of Colombo, using standard laboratory procedures in grain size analysis and clay/silt content. Samples weighing $30 \mathrm{~g}$ were treated with $\mathrm{H}_{2} \mathrm{O}_{2}(30 \%)$ and $\mathrm{HCl}(10 \%)$ so as to remove organic matter and carbonates, respectively. The samples were then washed and wet-sieved using a $0.062 \mathrm{~mm}$ sieve, the pan fractions being funneled directly into Liter sedimentation cylinders. Next, peptizer $\left(\mathrm{Na}_{4} \mathrm{P}_{2} \mathrm{O} \mathrm{IOH}_{2} \mathrm{O}+\mathrm{Na}_{2} \mathrm{CO}_{3}\right)$ was added and the cylinders were filled to the litre mark. After shaking, $20 \mathrm{ml}$ were removed from the cylinders and placed in nickel containers. After drying, the (silt+clay) contents were determined by weighing. The remaining $980 \mathrm{ml}$ suspensions were shaken again and allowed to settle. After some 16 hours, $20 \mathrm{ml}$ samples were again drawn from the cylinders, dried and weighed. The clay (and silt + clay) contents were then calculated using the formula:

$$
\frac{\text { observed weight }(\mathrm{g})-800(\mathrm{mg})}{\text { absolute dry weight }(\mathrm{g})} \times 50 \times 100 \%
$$

The $\mathrm{mg}$ represent the weight of the peptizer per $20 \mathrm{ml}$ sample. The difference in weight between (clay+silt) and clay is the silt content. The sand fraction $(>0.062 \mathrm{~mm})$ was dried in an oven for 24 hours at $105^{\circ} \mathrm{C}$. An electric sieve shaker with 10 sieves $(1.41,1.00,0.707,0.500,0.354,0.250$, $0.177,0.125,0.088$ and $0.062 \mathrm{~mm}$ ) was used to separate the grains according to size. Then the fractions were weighed.

The grain size distribution of a clastic sediment is a measure of the depositing medium and the energy of the basing. ${ }^{8}$ The depositing medium (or process) can be recognized if the grain size distributions are drawn into cumulative curves and histograms, etc, and then compared with each other. The technique is well explained by Reineck and Sing ${ }^{8}$ and is also used by Swan, ${ }^{12}$ for such studies in Sri Lanka. The laboratory data of 16 samples were drawn into cumulative curves and histograms aided by computer programme PLOTGRAINS. 6 Using the shape of the cumulative curves, and distributional patterns shown in the histogram, the origin of the material was investigated. For example, the shape of the cumulative curves of the barrier of Kalametiya and the planation surface at Batampara as shown in Figures 1 and 2 respectively, are different to each other in the shape of the cumulative 
curves and the distributional patterns shown in the histograms. The difference between the content of the silt/clay is also prominent because the processes of two landforms are different from each other. As the fossiliferous marine landforms identified from aerial photographs have been further ascertained by. such a recognized geomorphological technique, the map of landforms possess a highly accurate and scientific basis. Therefore, the former landforms recognizable are used here to postulate the heights and positions of the Mid-Holocene sea levels.

In addition, the shells of window pane oysters from a former beach and a former barrier were dated using $\mathrm{C}^{14}$ dating at Groningen University, Netherlands, so as to determine the absolute age of the recognized sea levels. However, no absolute dates for marine transgressions and regressions have been obtained prior to this study. Some observations however can be found in a few studies. ${ }^{9}, 10$ The $\mathrm{C}^{14}$ dates obtained by the author can be compared with the ages of Mid-H-rene sea level changes relating to other regions of the world.

\section{Results and Discussion}

\subsection{Evidence of Higher Sea Levels in the Kalametiya-Lunama lagoonal area}

The area of the Kalametiya-Lunama lagoons as shown in Figure 3 ( $\&$ \& b) are characterized by former bay beaches (unit BB) with shell beds commonly known as the Hathagala beds. Around the Kalametiya lagoon, the beds are prominent with huge colonization of Placenta placenta, a window pane oyster. The oysters' shells with marine sediments can be observed around the Kalametiya lagoon. These beaches are now situated around the present lagoons at a maximum height of $5 \mathrm{~m}$ above sea level.

Even though, the longest and widest beaches of this type can be seen around the Kalametiya and the Lunama lagoons, the continuation of the early beaches which correspond with a higher sea level is evident by shells, coral fragments and beach sands at many places around the Maha Lewaya (lagoon), Mahasittarakala, Ambilikala, Koholankala, Boondala lagoons, etc.

The so-called Hathagala beds, reported by several authors, 3,4 to consist of similar materials and beaches. These beds have been interpreted by these authors as estuarine deposits similar to Beira Lake deposits in Colombo and inland estuarine deposits. However, they did not study the height and the allied geomorphological features of the beds. These shell beds are found some $1-2 \mathrm{~km}$ inland of the present. beach and $5 \mathrm{~m}$ above the present sea level. The other places where such materials found are Lunama, Welipatanwila, Mahasittarakala, Malala, Udamalala, Maha Lewaya, Karagam Lewaya, 

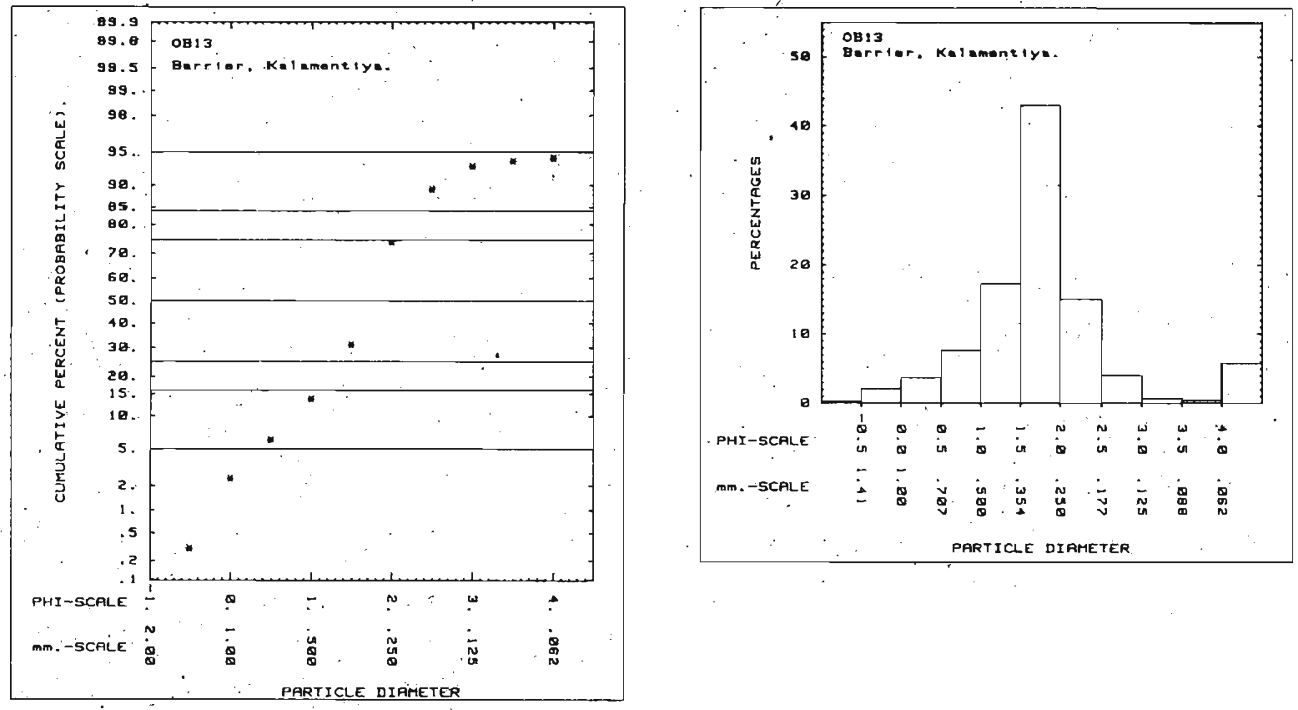

Figure 1. Grain size distribution of barrie of Kalametiya. Silt/clay content is shown in the histogram in the shaded column.
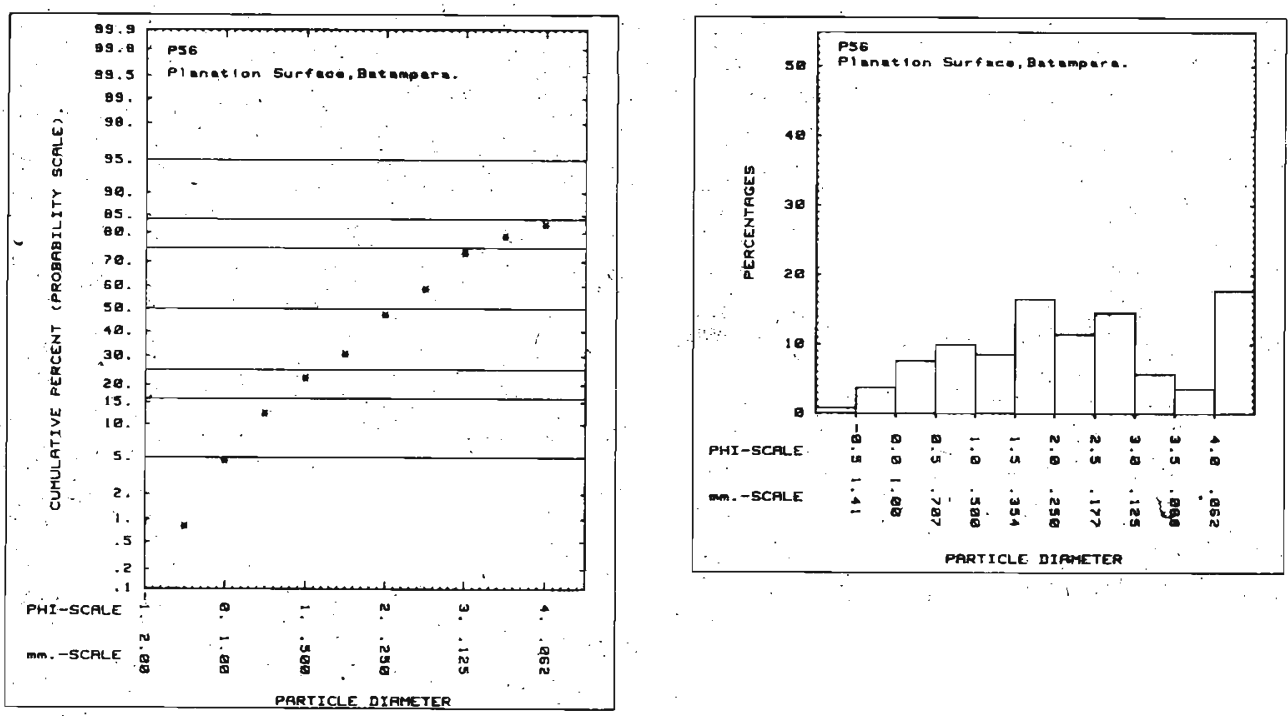

Figure 2. Grain size distribution of the planation surface at Batampara. Silt/clay content is shown in the shaded column. 


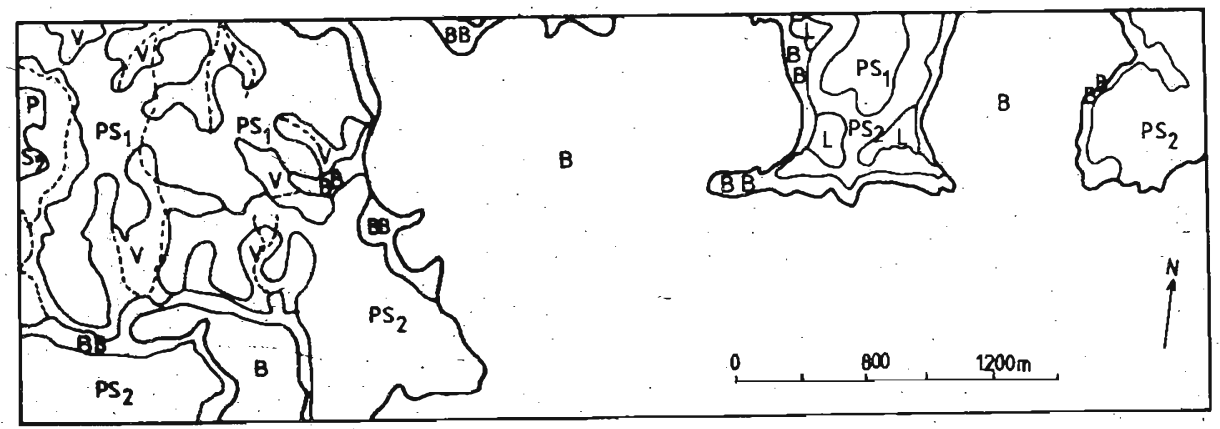

(a)

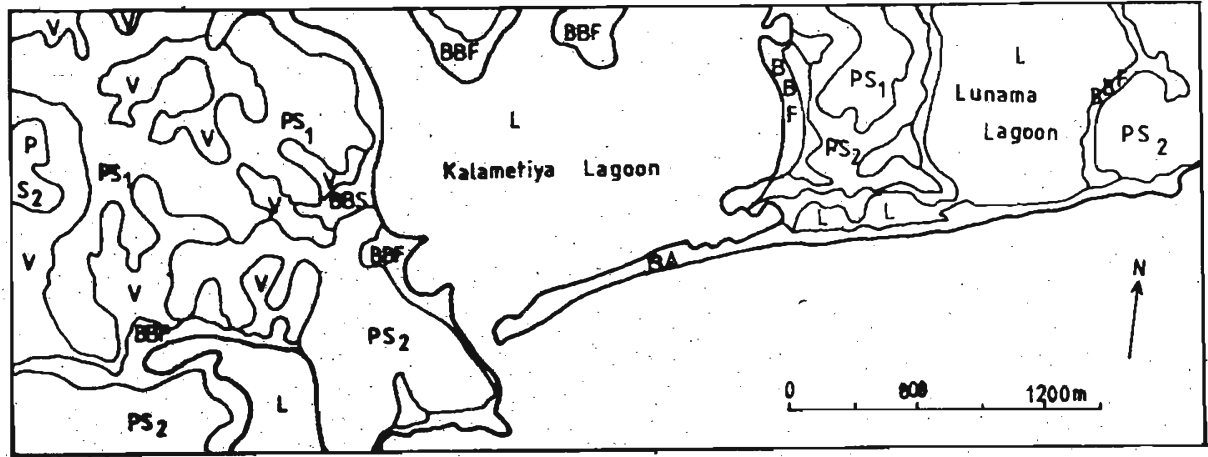

(b)

Figure 3 (a). The Kalametiya-Lunama lagoons during the Mid-Holocene period. The sea level was $5 \mathrm{~m}$ above the present sea level. Edges of the planation surfaces $\left(P S_{1}, P S_{2}\right)$ were submerged by this higher sea level forming deep embayments (B). The bays (B) were characterized by bay beaches (BB) inhabited by oyster colonies. Oyster-shells were preserved in the beds at several places, especially at Hatagala. Many streams flow from the valleys (V) into bays, and some submerged parts of the lowlands on the either side formed into small lagoons (L).

Figure 3 (b). The embayments were cut off by a chain of barriers (BA) when the sea level dropped from $+5 \mathrm{~m}$ to $+2 \mathrm{~m}$, and formed into the Kalametiya and Lunama lagoons. The present sea level is $2 \mathrm{~m}$ below the barrier chain. 
Embilikala, Bundala, etc. These are evidences of a sea level at $5 \mathrm{~m}$ above, and the beaches were formed by early embayment environment associated with low energy and created by refracted waves entering into baylets. ${ }^{19}$ When the sea level dropped from $+5 \mathrm{~m}$ to $+2 \mathrm{~m}$, it formed a barrier chain and cut off the bays from the sea and the ultimate result was a conversion of bays into lagoons (Figure 3). This barrier formation stage suggests a dropping of the sea level from $5 \mathrm{~m}$ to $2 \mathrm{~m}$ because the barrier chains are now situated at $2 \mathrm{~m}$ above the present sea level.

4.2 Evidence for higher sea levels in the Koholankala lagoon and the Minihagalkanda beds

The former ${ }^{\text {Bay }}$ of Koholankala' was of a funneled shape ${ }^{19}$ when the sea level was $+5 \mathrm{~m}$ (Figure $5 \mathrm{a}$ ). The narrow northern part of the bay was submerged by former sea level and therefore, the river sediments were deposited in the northern end of the bay when the sea level was lowering. When sea level was lowered further, an embayment barrier (unit BF1) and a huge spit (unit SF2) formed, of fine materials derived from the hinterland (Figure $5 \mathrm{~b} \& \mathrm{c}$ ). During the later stage, when the sea level dropped to $2 \mathrm{~m}$, a chain of barriers formed in front of the 'Bay of Koholankala' and cut off the bay, to form the present Koholankala lagoon (Figure $5 \mathrm{~d}$ ). Horizontal development of the lagoon is further illustrated by Figure 6 .

The highest position of the sea level is recorded in Minihagalkanda beds in the Yala National park. According to the note made by Deraniyagala, ${ }^{5}$ the author investigated into marine terraces that may be cut off by possible early sea levels, using aerial photographs in triplets with the help of a Mirror stereoscope and a Parallex Bar, and the interpretation* is shown in Figure 7. The beds were formed during the Lower Miocene. ${ }^{3}$ During marine transgressions three terraces were cut into the seaward edge of the beds, reflecting three main sea levels. Parallax measurements of the terraces reveal that two of them were situated more than $5 \mathrm{~m}$ above the present sea level. They could be Pleistocene higher sea levels marked on these Miocene beds.

The evidence derived from the Kalametiya, Lunama and Koholankala lagoons contributes to position the two sea levels at the $5 \mathrm{~m}$ and $2 \mathrm{~m}$ above present sea level. As the dating is necessary to evaluate the real age of the highest sea level, the shells collected from the Kalametiya $5 \mathrm{~m}$ beach, and from the mid-bay bar of the Koholankala lagoon were tested and the results can be shown as follows;

$5 \mathrm{~m}$ beach (Kalametiya bay beach) $\quad 3620 \pm 70 \mathrm{BP} \#(9-\mathrm{GrN}-13306)$ $5 \mathrm{~m}$ beach (mid-bay bar of Koholankala) $4040 \pm 70 \mathrm{BP}$. \# (69-GrN-13308)

- Due to insurgent activities during the field work, the author was not allowed to enter the area which is under the Department of Wildlife, therefore, field measurements could not be carried out. 


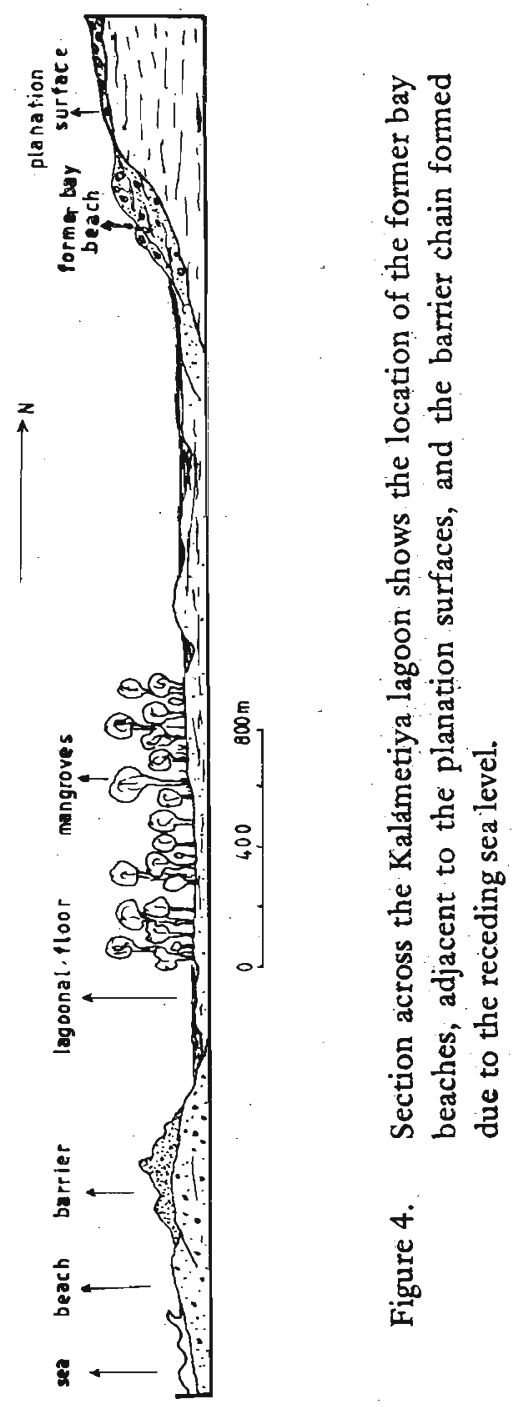




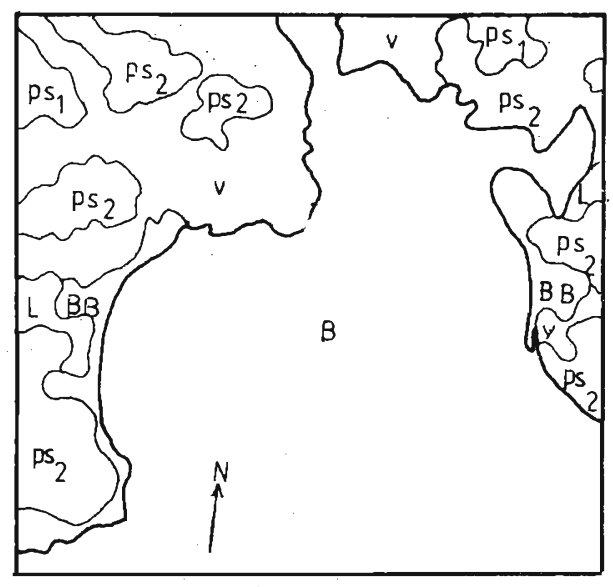

(a)
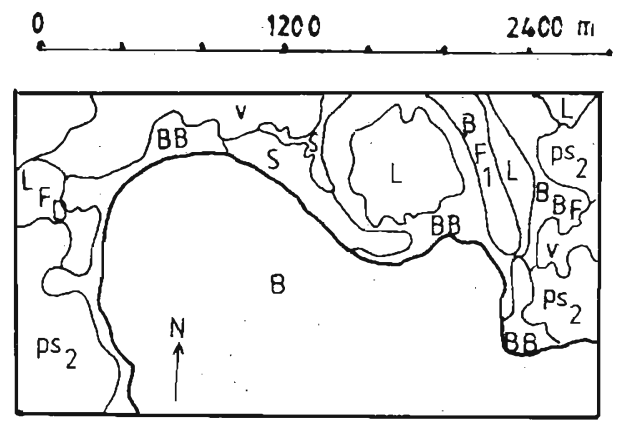

(c)

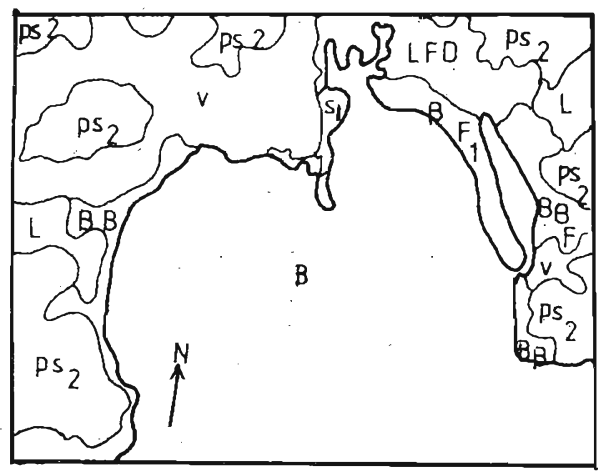

(b)

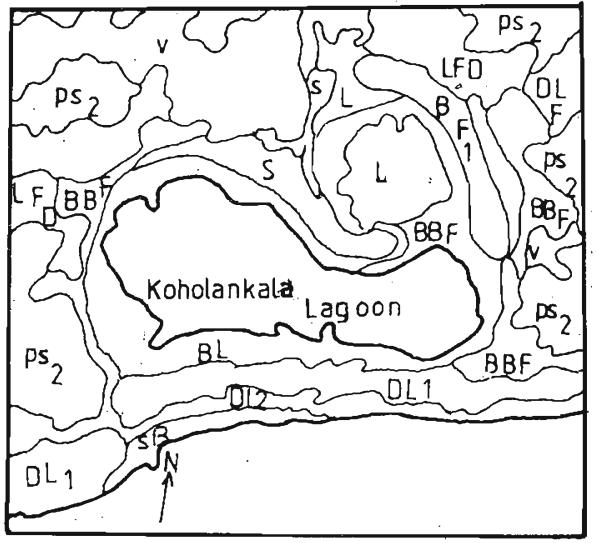

(d)

Figure 5. The effect of sea level changes on the development of the Koholankala lagoon in four stages since Mid-Holocene. (a) The planation surfaces (PS 1 , $\mathrm{PS}_{2}$ ) and valleys $(\mathrm{V})$ were submerged by the marine transgression to form a funnel-shaped embayment (B) and bay beaches. (BB).. (b) When the sea level dropped, a mid-bay bar $\left(\mathrm{BF}_{1}\right)$ and an incipient spit $\left(\mathrm{S}_{1}\right)$ were formed in front of the neck of the funnel. Subsequently lagoons (L) were dried out forming dried out lagoonal floors (DLF). (c) Due to the gradual dropping of the sea level, the incipient spit grew larger (S). (d) The oval-shaped bay formed during the third stage (c), ultimately: was cut off from the sea by a chain of barriers crownwed by sand dunes $\left(\mathrm{DL}_{1}, \mathrm{DL}_{2}\right)$. The Koholankala lagoon is now characterized by wide lagoonal beaches (BL). 


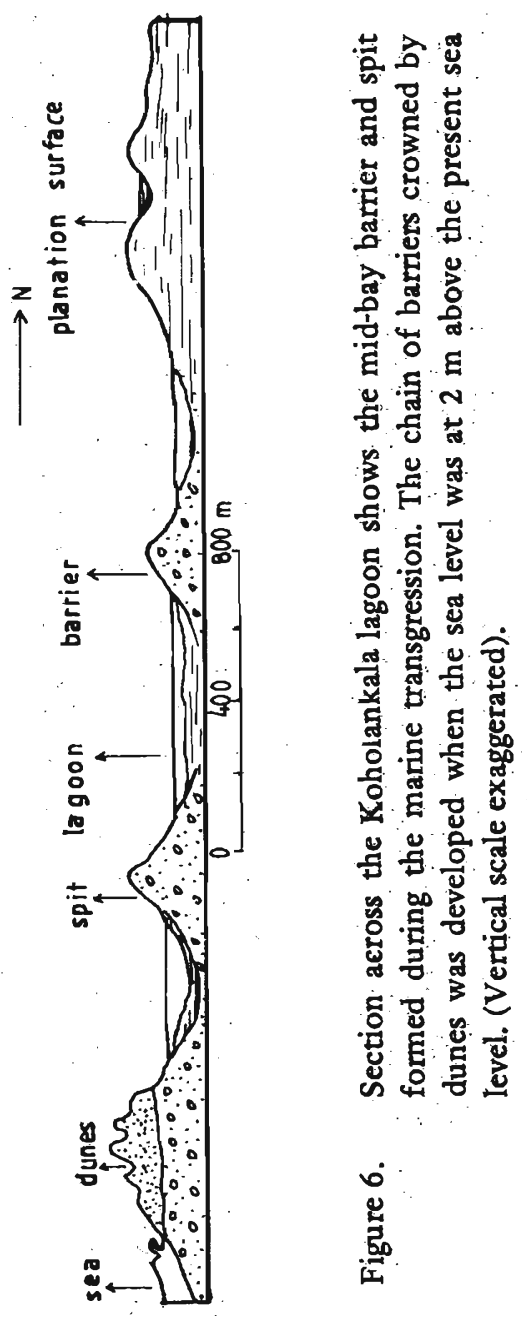




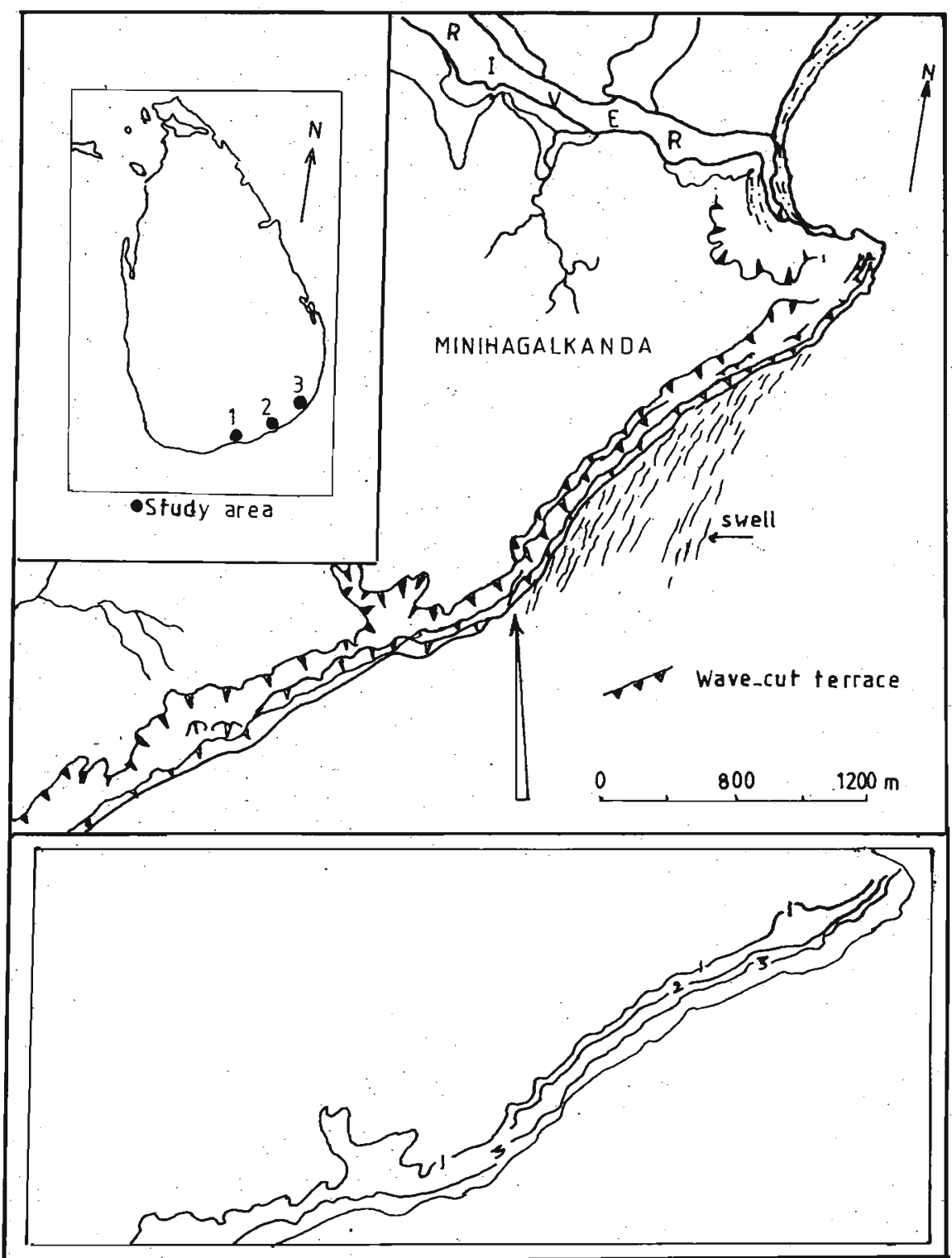

Figure 7. The marine terraces on the Minihagalkanda beds cut by unknown early higher sea levels. The lower insert map denotes the relative elevation as 1 . (high), 2. (middle), and 3 (low). The upper insert shows the location of study areas, as 1. The Kalametiya Lunama lagoons, 2. The Koholankala lagoon and 3. The Minihagalkanda beds. 
Accordingly, the highest sea level can be dated as around $4000 \mathrm{BP}$. However, samples could not be derived from the Minihagalkanda beds, and therefore, the lower marine terrace can only be considered here as a qualitative evidence for higher sea level in the region.

\section{Conclusions}

The eustatic sea levels have risen from $14,000 \mathrm{BP}$ to at least $4000 \mathrm{BP}$ in several regions of the world. The figures calculated according to several sources, showed that the sea level of the $4000 \mathrm{BP}$ was higher than the present sea level. According to Fairbridge, ${ }^{7}$ the sea level of $7000 \mathrm{BP}$ which was at least $6 \mathrm{~m}$ above the present sea level, dropped to zero in $6000 \mathrm{BP}$. Then the sea level again rose upto $+3 \mathrm{~m}$ in $5000 \mathrm{BP}$ and dropped to $+2 \mathrm{~m}$ in $4000 \mathrm{BP}$. Scofield ${ }^{7}$ mentions however, that the sea level of $4000 \mathrm{BP}$ was $+5 \mathrm{~m}$ above the present sea level. All these investigations prove that the sea level in the Mid-Holocene period was higher than that of the present.

However, Swan ${ }^{12}$ mentions several possible time periods during which the elevated beaches of Sri Lanka may have been formed: the last Monastirian $(90,000-95,000 \mathrm{BP}), 3 \mathrm{~m}$ beach during the late Monastirian $(75,000-$ $80,000 \mathrm{BP})$ or one of the Peron subsidences $(3,400=6000 \mathrm{BP})$. The uncertainity of the age of the elevated beaches in the southeast part of Sri Lanka is clarified by the present $\mathrm{C}^{14}$ dating. On the other hand, there are no evidences to postulate that the materials of the elevated beaches of the area were formed as early as 75,000 to $95,000 \mathrm{BP}$, , because all these deposits consist of unconsolidated materials. The barrier formed in the early embayment of Koholankala still remains in its original morphological form, and even minor deformations cannot be observed. The radiocarbon! dating, nature of the morphology of the beaches of the Kalametiya-Lunama and Koholankala lagoonal areas and the marine terraces of the Minihasgalkanda beds may weil be a marine transgression which submerged the south-east coast of Sri Lanka during the Mid-Holocene period. Further support for such an assumption can be obtained from other studies relating to Sri Lanka. Data point contributing to a eustatic sea level curve taken from a wide range of supposedly stable areas proves that the sea level in Sri Lanka dating $3000 \mathrm{BP}$ was $4 \mathrm{~m} .9$ All these evidences confirm a Mid-Holocene marine transgression from $5 \mathrm{~m}$ and a regression at $2 \mathrm{~m}$ which effected considerable changes in the coastline of Sri Lanka.

\section{Acknowledgements}

I wish to express my deep gratitude to Prof. Kanthi Ratnayake of the University of Ruhuna for having read the entire manuscript and for offering 
valuable constructive criticism. I am also grateful to Prof. H. Th. Verstappen of the ITC, the Netherlands, who supervised the research. The analysis of materials for $\mathrm{C}^{14}$ dating also was possible owing to the support given by him. I extend special thanks to the ITC for rendering financial support for the project.

\section{References}

1. ADAMS, F.D. (1929) The Geology of Ceylon. Can. J. Research; 1: 425-511.

2. COATES, J.S. (1936) The Geology of Ceylon. Spol. Zeylanica, 19(2) 101-187.

3. COORAY, P.G. (1967) An Introduction to Geology of Ceylon. National Museum, Colombo.

4. DANIEL, J.A. (1908) Mineralogical Survey of Ceylon. Administr. Report, Colombo.

5. DERANIYAGALA, P.E.P. (1958). The Pleistocene of Ceylon. National Museum, Colombo.

6. DONKER, N.H.W. (1985) Documentation Programme Enteri and Programme PLOTGRAINS. Unpublished Report, I T C, the Netherlands.

7. GOUDIE, A. (1977) Environmental Changes. Clarendon Press, Oxford.

8. REINECK, H.E. \& SINGH; I.B. (1980) Depositional Sedimentary Environments. 2nd Review, Springer Verlag, NY.

9. ROSE, J. (1981) 'Raised Shorelines' in Geomorphological Techniques, Ed. A. Goudie. George Allen \& Anwin; Boston.

10. SHEPARD, F.P. (1964) Criteria in modern sediments useful in recognizing ancient sedimentary environments. Dev. in Sed. 1: 1-25.

11. SWAN, B. (1974) Coastal Erosion Hazard of the Soutbwest Sri Lanka. University of New England, Aust.

12. SWAN, B. (1967) Characteristics of Coastal Sands and their Depositional Environments in Southwest Ceylon. J. Tropi. Geog. 24: (June) 30-42.

13. SWAN, B. (1982) The Coastal Geomorphology of Sri Lanka; An Introductory Survey, University of New England, Aust. 
14. VAN ZUIDAM, R.A. \&.VAN ZUIDAM-CANCELADO, F.I. (1978) Terrain Classification and Analysis, 6: I T C; the Netherlands.

15. WADIA, D.N. (1945) The three Superposed Peniplains of Ceylon; their physiography and geological structure. Records of Development of Mineralogy. Prof. Pap. No. 1 , Colombo.

16. WAYLAND, E.J. (1921) Fossiliferous Beds in Ceylon. Spol. Zeylanica, 11: 407-8.

17. WEERAKKODY, U. (1983) An Analysis of the Chronology of the Southwest Coastline of Sri Lanka. Proc. 39th Ann. Sess. Ass. Adv. Sci. Sri Lanka.

18. WEERAKKODY, U. (1985) Landform Evolution and Sediment Dynamics of Depositional Coasts; An Aerospace Survey Approach. (unpublished); I T C, the Netherlands.

19. WEERAKKODY, U. (1985) Geomorphological Evolution of the Southeast Coast of Sri Lanka, MSc thesis, I.T.C. the Netherlands.

20. WEERAKKODY, U. (1986) Geomorphological Evolution of the Koholankala Lagoon, ROHANA-Research J. of the University of Rubuna, Np. 2. 1986 (in press).

21. WEERAKKODY, U. (1986) Geomorphological Evolution of the KalametiyaLunama Lagoons. Proc. 42 nd Ann. Sess. Ass. Adv. Sci, Sri Lanka. 